UNTAG Law Review (ULREV)

Volume 2, Issue 2, Nov 2018, PP 189-199

ISSN 2549-4910 (online) \& ISSN 2579-5279 (print)

http://jurnal.untagsmg.ac.id/indeks.php/ulrev/indeks

www.fakhukum.untagsmg.ac.id

\title{
PREVENTING AND FIGHTING CORRUPTION THROUGH PUBLIC POLICIES
}

\section{Dr. Drs. H. Dudu Duswara Machmudin S.H., M.Hum.}

Faculty of Law, Langlangbuana University, Bandung

\begin{abstract}
Law enforcement does not engage in a vaccum space, yet it is related to variables of socio-political condition, mental of the law enforcers, criminal law procedures, law ideology, NGOs, and legal awareness of the society. Moreover, fighting corruption through law enforcement demands collective awareness as stakeholders to actively participate in national efforts to prevent and eradicate corruption. Measures taken on the prevention must be built in socio-political climate and national collective culture which enforce zero tolerance to any forms of corruption, including bribery, gratification, trading influence, illicit enrichment, corporate corruption, political corruption, collusion, and nepotism.
\end{abstract}

Keywords : Preventing Corruption Public Policies

\section{INTRODUCTION}

Corruption in Indonesia

Rampant corruption is a big problem being faced by Indonesia nowadays in 2017, especially political corruption. Corruption is the factor that constraints economic, social, political, and cultural development of this nation. Indonesia has classified corruption as an extraordinary crime since Law Number 30 of 2002 on the Indonesian Corruption Eradication Commission (KPK) came into force. It is deemed extraordinary because corruption in Indonesia has spread widely and systematically, violating economic rights of the society. Therefore, extraordinary measures need to be undertaken.

The spirits of Law Number 31 of 1999, Law Number 20 of 2001, and Law Number 30 of 2002, are bound in the spirit of international community to articulate the Declaration of $8^{\text {th }}$ International Conference Against Corruption held in Lima, Peru from 7 - 11 September 1977 for the combat of corruption at the international level. Indonesia also has addressed legal steps to ratify United Nations Convention Against Corruption (UNCAC) pursuant to 58/4 Resolution dated 31 October 2003, as stipulated in Law Number 7 of 2006 on Ratification of the United Nations Convention Against Corruption, 2003. 
The morale postulate behind the born of United Nations Convention Against Corruption 2003, among others, was because corruption had become international phenomenon which affected politics, economics and other aspects of life. The intensity of corruption was considered threatening the values of democracy, ethic, and also disrupts sustained development, as well as law enforcement.

\section{Efforts in Fighting Corruption}

Indonesia, as one of the state parties that has ratified the UN Convention Against Corruption, is encouraged to eradicate corruption effectively by using its national legal system and other instruments of international law on corruption. The existence of UN Convention Against Corruption has made corruption - in Indonesia and other countries ratifying UN Convention Against Corruption - is classified an international crime. Consequently, it carries a connotation that stakeholders of the corruption itself and its resolution process become wider. If the corruption occurs in Indonesia, foreign investors, World Bank, and foreign financial institutions may be the aggrieved parties when it involves their rights and interests in Indonesia. Accordingly, all parties involved and morally concerned with corruption are not only the perpetrators of the corruption, but also the nation, Indonesia and its people, as well as the international community. Corruption that inflicts state financial and economic losses has been - and will always be - depriving public (stakeholder) strategic rights to live properly.

Being categorized as extraordinary crime in human rights crime, it becomes an obligation of the state (Orga Omnes Obligation) to bring it to justice because extraordinary crimes belongs to Hostis Humanis Generis domain or the enemy of mankind. In his book entitled The Spirit of Democracy, which studies corruption crimes and human rights crimes, Larry Diamond asserts that To be sure, Indonesia remains a troubled democracy with an extremely weak rule of law. Abuse of public office for private gain remains endemic..... Corrupt relationships between powerful private actors, government bureaucrats, politicians and security officials infuse the political system and undermine it from within. As a result oligarchic business interest exercises a preponderant influence on parties, legislatures, and the executive. Corruption seeps deep into many local administration, often hand in hand with egregious human right abuses. (Diamond, 2008:220). Thus, according to Larry Diamond, Indonesia is still having problems with the implementation of democracy and weak law enforcement. Misuse of government institution for personal interests is still prevalent. Corrupt practices between influential people from private sector and public officials, politicians and police officers pervade the political system and spoil it from the within. Consequently, interests from a small group of people may overwhelm interests from political parties, House members, and government officials. Corruption mostly occurs in regional government and oftenly corellates with violation of 
human rights.

Victims of corruption are nations and the people since it incurs state financial and economic loss. Moreover, the victims come from lower-income people and those who are politically vulnerable. The poor become unable to live properly and their children are hardly to get appropriate education. Corruptors make the nation as the victim (Victim State). Therefore, strong law instruments are required to combat corruption. Quoting from Plato, a Greek philosopher, Amartya Sen reveals in his book entitled Development As Freedom that Plato suggested in the Laws that a strong sense of duty would help to prevent corruption (Sen, 1999:127), thereby demanding shared responsibility which is strong enough to prevent corruption.

Corruption crime inflicts both directly and indirectly financial and economic loss on the nation, and the people at the same time. Therefore, efforts to fight against corruption will be unrealistic if people are not involved as the stakeholders. In Article 41 of Law Number 31 of 1999 on the Eradication of Corruption Criminal Act, the role of society is determined. This opportunity appears as logical consequences of the position of the people in a democracy as stakeholders in the life of the people and the nation. Similarly, the UN Convention against Corruption in Article 13 ensures community participation. Among others, it asserts that nation is obliged to take appropriate action, within its authority, and in accordance with the fundamental principles of its national law, to increase active participation of individuals and groups outside the public sector, such as civil society, non-governmental and communitybased organizations, in the prevention of and the fight against corruption, as well as increasing public awareness regarding the existence, causes and gravity, as well as the threat of corruption.

\section{Strategies Undertaken}

In order to eradicate corruption, the society is juridically provided legal mandate to give social contributions, which is to interact and hand in hand with law enforcers in fighting against corruption and, in broader range, creating good governance. The implementation of the role of society (NGOs, mass organizations, universities, mass Media) can be actualized in control activity, monitoring, proposing concepts, and the like. Ethical consequences of the role of community participation come together with the effectiveness of the implementation of Law Number 13 of 2006 on Witness and Victim Protection is a necessity. In the case of corruption, it is a guarantee of the right to obtain legal protection for people who provide information regarding alleged corruption as defined in article 41 paragraph $2 \mathrm{~d}$ of Law Number 31 of 1999. 


\section{Hyphothesis Construction Scheme for Criminal Act \\ Based on Law No. 31 of 1999}

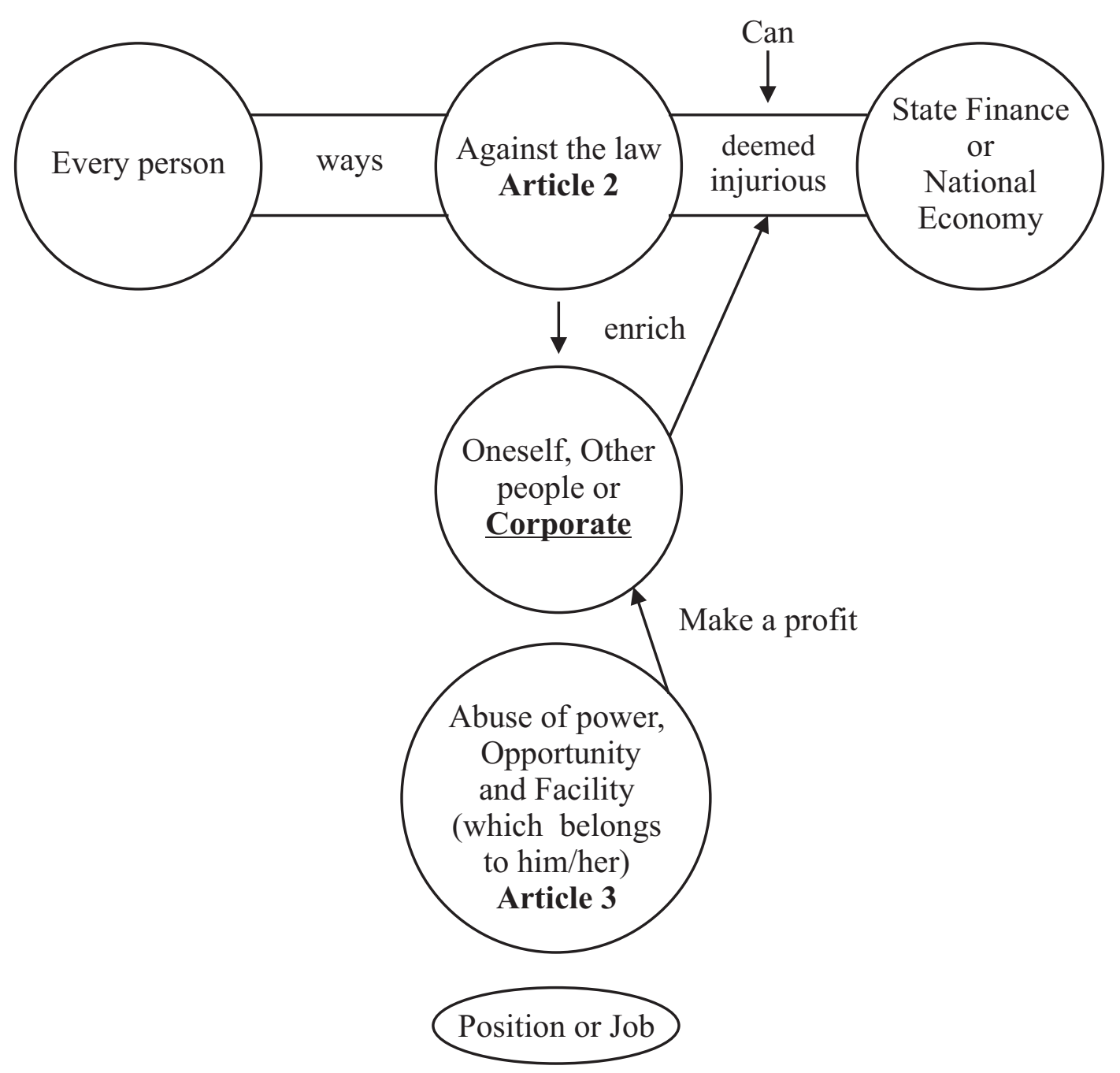




\section{Hyphothesis Construction Scheme for}

\section{Constellation Components of the Actors and the Results of Political Corruption}

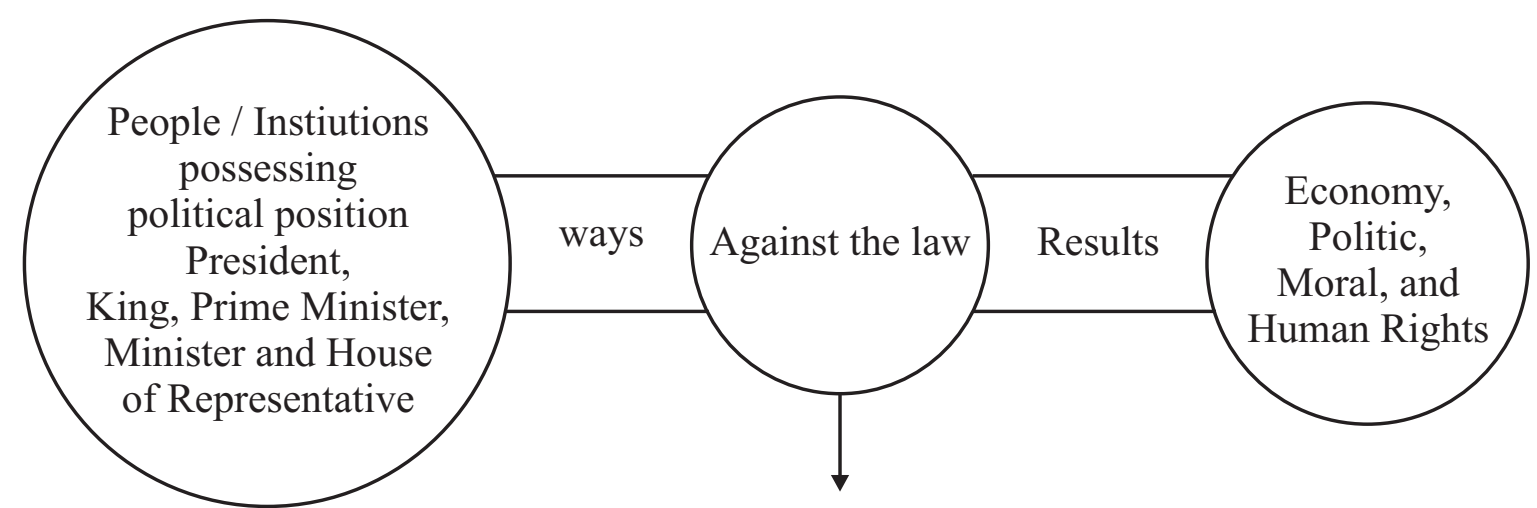

to benefit

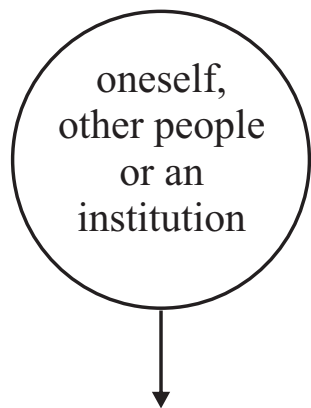

misuse

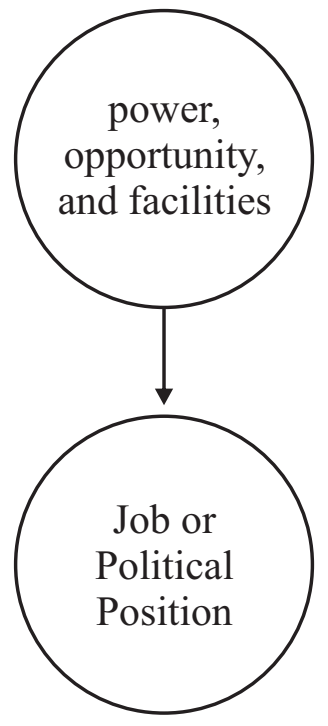




\section{Politic Corruption Scheme and Influential Factors}

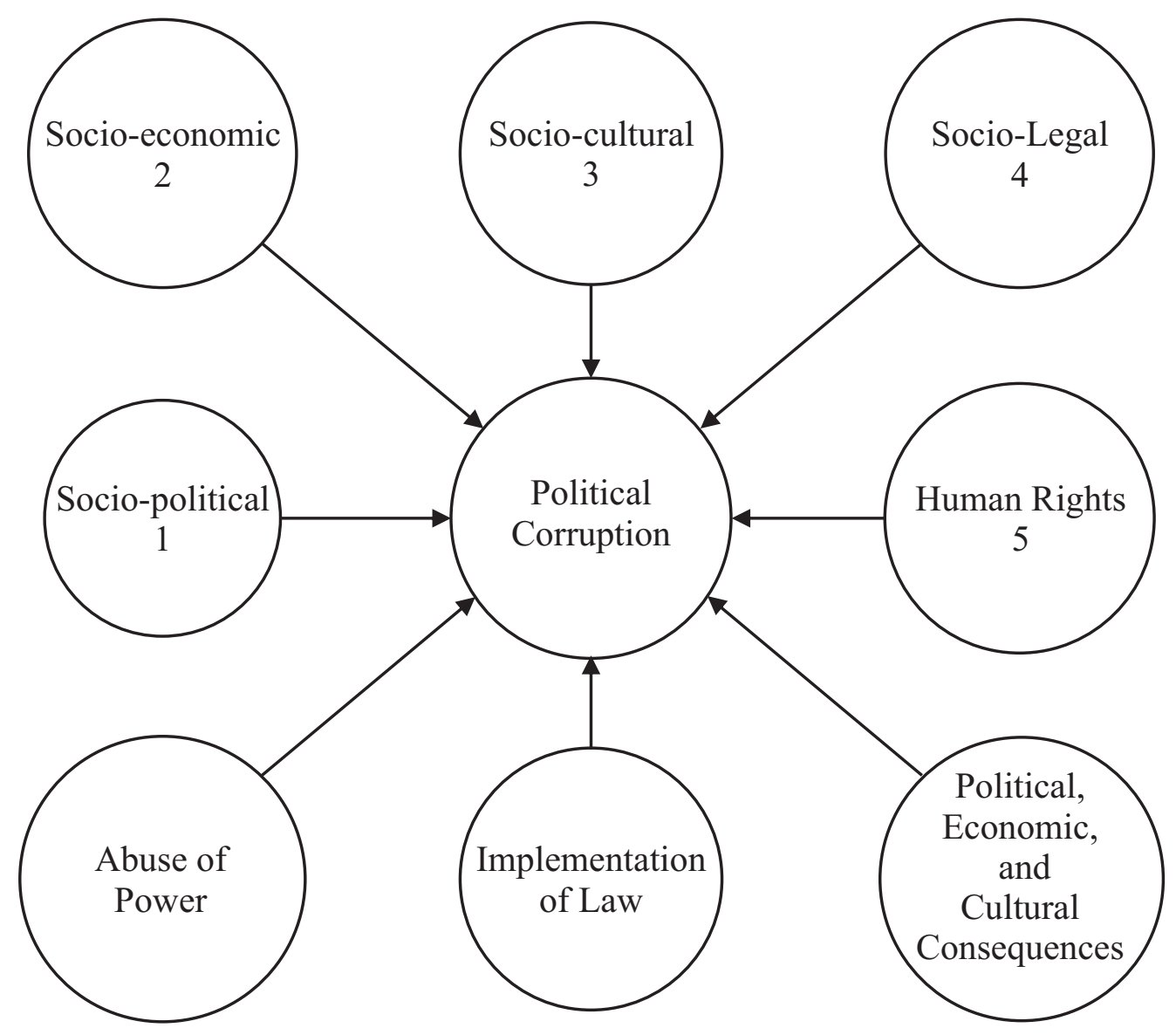


The Chronological Scheme of Penal Instrument on Corruption Prevention Efforts
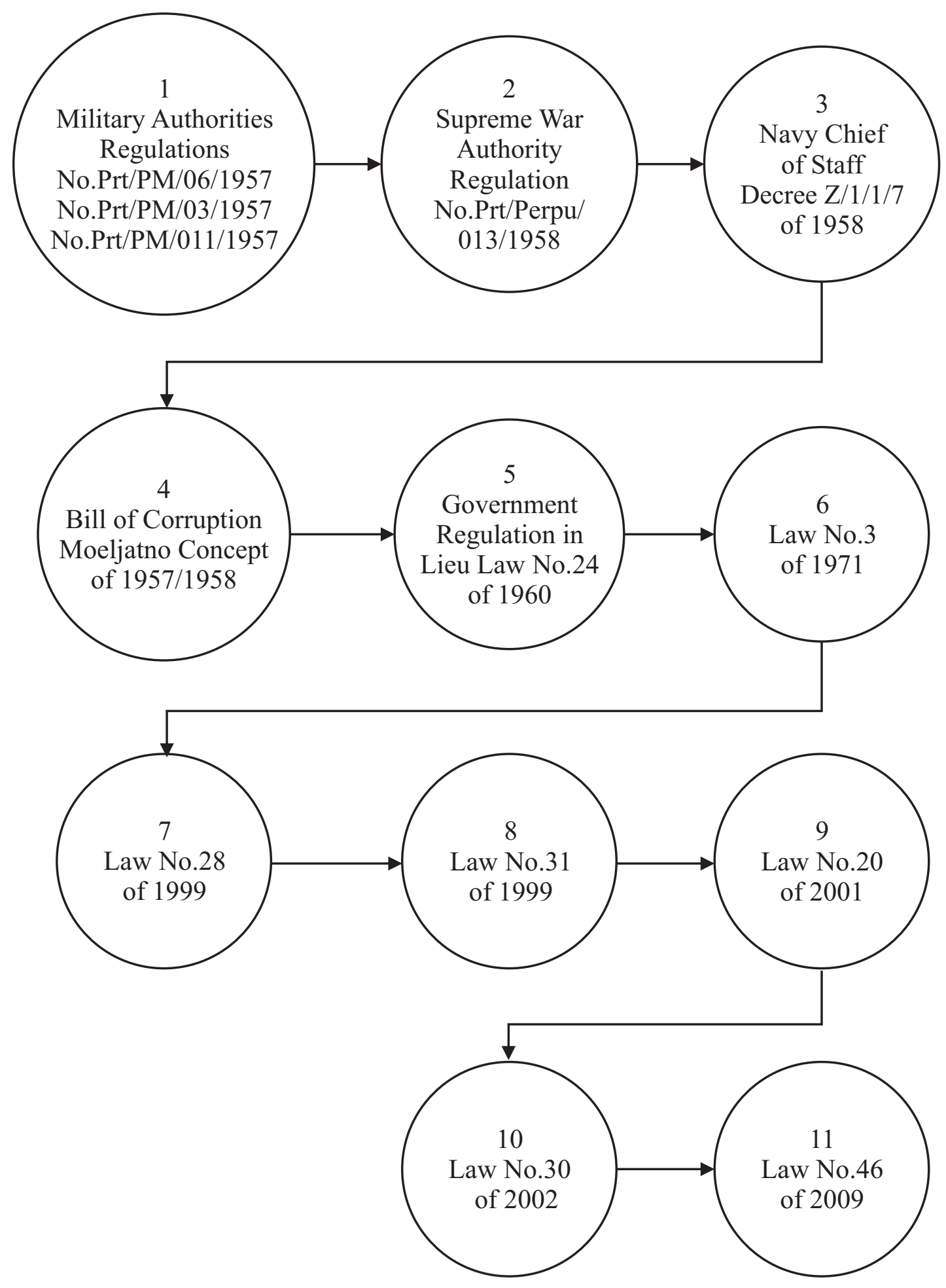


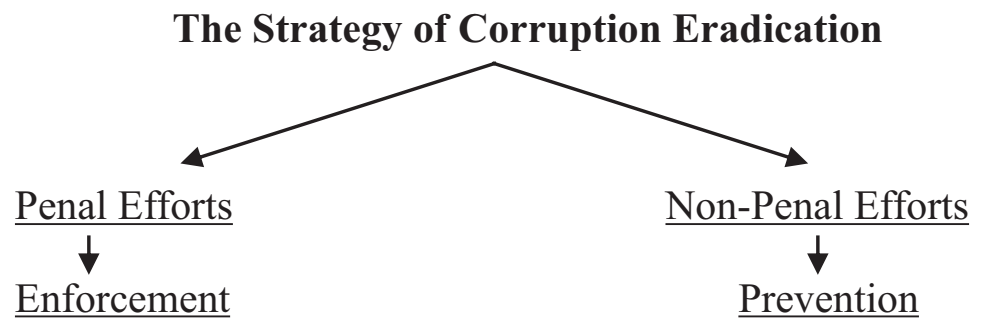

Law Enforcement

Legality X $\left\{\begin{array}{c}\text { Opportunity } \\ \text { Feudalization } \\ \text { of Law }\end{array}\right.$

The Formation of Corruption

Eradication Commission

Pre-trial, sufficient evidence.

Prosecution Strategies versus

Selective feeling

Maximum Criminal Sentence commensurate with the dangerour level of the corruption committed
Analysis of Corruption Patterns

System - systemic corruption requires systemic approach

Strategy - priority

Momentum

Community Participation

Erode the culture of cynicism and apathy in combating corruption

Fend off all forms of behaviour and acts politically, juridically, as well as socially from any parties who are in danger by the implementation of anti-corruption law .

Root out out all seeds and matters that may foster corruption.

Ratify and enact international conventions on corruption 
Corruption manifests in various modes of operation which are collusive and confidential in nature. It includes briberies from contractors to state officials or state actors. This typology of corruption has once occurred in the United States of America, as revealed by Earl R Sikes in his book entitled State And Federal Corrupt-Practices Legislation. He said that contractors, hoping to insure the election of friends who will be in a position to award lucrative contracts, often contribute generously to the party fund. Trough corrupt agreements between public official anda contractors these contrutions have at time degenerated into outright stealing from taxpayer. (Sikes, 1928:118). Thus, corrupt agreement between the state officials and the contractors from time to time has been deteriorating as it goes on to the (actual) stage when it deprives the taxpayers' rights. The connotation of this condition is regarded causing loosses to the wealth of the country and the public money.

\section{State Finance}

Juridically, it is asserted in the elucidation of Law Number 31 of 1999 on State Finance which explains that state finance is all state assets in any form whatsoever, either separated or not separated, including within it, all parts of state assets and all rights and liabilities incurred due to: a) being under the control, management and responsibility of a state institution official, both in the central government and the regional government; b) being under the control, management and responsibility of state-owned or regional-owned enterprises, foundations, legal entities, and companies having third party capital based on agreement with the state.

\section{Public Policies}

\section{As elaborated by Riant Nugroho (2009:51-52), public policy is a dynamic three dimensions form of life of every nation, namely :}

1. Political Dimension, it is because public policy is the most concrete form of political system applied. Democratic Politics provides the results of public policies which are enggaged in democratic process and built for public interests - not for individuals or certain groups of people.

2. Law Dimension, it is because public policies are legal and nation facts, thereby public policies are bound to people of the nation and also all state actors, especially the state executives. This is emphasized because bad law applies only to people (especially to the poor ones) and leaves behind legislators or law enforcers (or ellites).

3. Management Dimension, it is because public policies are designed or planned, and then implemented by various organizations and institutions, and led by the government along with its executive organizations, which is the bureaucracy, together with people. To achieve optimum results, public policy shall be carefully managed. Planning, organizing, 
leading, and controlling are the functions of management.

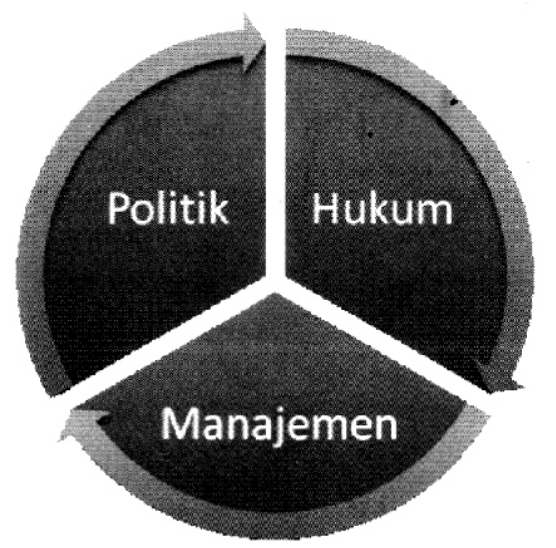

Three Dimensions Forming Public Policy

Public policy is actually a political process which is justified by a democratic nation inorder to achieve good governance. Implementing good and transparent governance may prevent the occurrence of abuse of power.

In relation to law enforcement, democracy, wealth and economy, Jeffrey A. Winters (2011:282) believes that:

A second observation has deep implications for literatures focused on the relationship of law to democracy, property, and the economy (especially markets). In this study, the treatment of the rule of law was not as a systemic matter. The approach was instead from the perspective of individual capacities of citizens to intimidate or distort the law. The low rule of law exists when the great majority of citizens routinely submit to the legal system because they lack the power resources to deflect police investigations and prosecutions or distort the decisions of judges. Whatever problems there may be with the legal system are technical in nature and can be improved through training, spending on infrastructure, and other common developmental projects focused on the rule of law.

\section{Prevent and Fight Corruption.}

Law enforcement does not engage in a vaccum space, yet it is related to variables of sociopolitical condition, mental of the law enforcers, criminal law procedures, law ideology, NGOs, and legal awareness of the society. Moreover, fighting corruption through law enforcement demands collective awareness as stakeholders to actively participate in national efforts to prevent and eradicate corruption. Measures taken on the prevention must be built in sociopolitical climate and national collective culture which enforce zero tolerance to any forms of corruption, including bribery, gratification, trading influence, illicit enrichment, corporate corruption, political corruption, collusion, and nepotism. 
Dr. Drs. H. Dudu Duswara Machmudin S.H., M.Hum. : Preventing And Fighting Corruption

\section{References:}

Alkostar, Artidjo, Korupsi Politik di Negara Modern, FH.UII Press, Yogyakarta, 2008.

Epstein, Lee, \& Knight, Jack, The Choices Justices Make, Congressional Quaterly, Inc, Washington DC, 1998.

Friedman, Lawrence M, Total Justice, Beacon Press, Boston, 1985.

Malkin, Michelle, Culture of Corruption, Regnery Publishing, Inc, Washington DC, 2009.

Nugroho, Riant, Public Policy (edisi revisi), PT. Elex Media Komputindo, Jakarta, 2009.

Sandel, Michael J, What Money Can't Buy, Farrar, Straus and Giroux, New York, 2012.

Sen, Amartya, Development as Freedom, Achor Books, New York, 1999.

Sikes, Earl. R, State and Federal Corrupt-Practices Legislation, Duke University Press, Durham NC, 1928

Winters, Jeffrey A, Oligarki (translated), PT. Gramedia PustakaUtama, Jakarta, 2011. 